LEHOTAY Veronika

DOI: 10.15170/DIKE.2019.03.02.05

egyetemi adjunktus

ME ÁJK

\title{
Büntetőjogi joggyakorlat a Miskolci Királyi Törvényszéken 1944-ben ${ }^{1}$
}

\author{
„... a kép ettól összetettebb \\ és mindenképpen árnyaltabb."’2
}

\section{Criminal Law Practice of the Royal Court of Miskolc in 1944}

This essay focuses on criminal suits in the Court of Justice in Miskolc (county capital of Borsod-Abaüj-Zemplén in Hungary) during World War II. It analyses the content and the number of different cases. The number of cases was about 'slandering the Hungarian state and nation', dissemination of false news, and incitement to Hungarian armed forces. The study reveals that very few numbers of cases related to the Anti-Jewish laws in county Borsod, which was rather characteristic in the countryside out of Budapest. For example, in 1943 and 1944, only four trials based on race defilement.

Keywords: practice of law, criminal law, Miskolc, 1944, anti-Jewish law, Royal Court of Miskolc

\section{Bevezetés}

Jelen tanulmányban a Miskolci Királyi Törvényszéken 1944-ben zajló büntetőpereket vizsgálom. A büntetőjogban változást hoztak egyrészt a háborúra való készülődést célzó, másrészt pedig a jogkorlátozó, illetve a zsidótörvényekben foglalt rendelkezések megszegését szankcionáló szabályok. Az országban a háborús években folyamatosan emelkedett a bűnügyek száma. A diszkriminatív büntetőjogi joggyakorlatot Ausztriában és Németországban is feltárták a kutatók. A német jogtörténészek közül Eva Schumann, ${ }^{3}$ Thomas Vormbaum, ${ }^{4}$ Wolfgang Form, ${ }^{5}$ Joachim Voget ${ }^{\natural}$, míg

\footnotetext{
1 A tanulmány a "Jogfosztás elmélete és gyakorlata a Horthy-korszak másodike felében az NS-rendszer tükében” c. tudományos ülésen (Pécs, 2019. szeptember 2-6.) elhangzott elöadás szerkesztett változata.

${ }^{2}$ NAGY, A fajvédelem útvesztőjében 488.

3 Schumann, Kontinuitäten und Zäsuren. Rechtswissenschaft und Juristen im „Dritten Reich” und in der Nachkriegszeit.

${ }^{4}$ VORMBAUM, Einführung in die moderne Strafrechtsgeschichte.

${ }^{5}$ FORM, Literatur- und Urteilsverzeichnis zum politischen NS-Strafrechts.

${ }^{6}$ VoGEL, Einflüsse des Nationalsozialismus auf das Strafrecht.
} 
az osztrák jogtörténészek közül a témával többek között Ilse Reiter-Zatloukal', Johanna Schmitz̧berger foglalkozik. Tanulmányok, monográfiák születtek a megváltozott büntetőjogról, az igazságszolgáltatás átalakulásáról, a büntetőjogi gondolkodókról. ${ }^{9}$ Ezzel szemben a magyarországi szakirodalomban a két világháború büntetőjogának, a zsidótörvények felsőbb bírósági, és ehhez kapcsolódóan helyi szintű bírósági gyakorlata és az ügyészség múködése is feltáratlan területe a jogtörténetnek.

A kutatás során és a tanulmányban a következő kérdésekre keresem a választ. Hogyan változtak a bűncselekményi kategóriák a jogkorlátozó törvények és a háború hatására? Milyen ítéletek születtek? Milyen szerepe volt Miskolci Királyi Törvényszéknek az 1938 és 1944 között született zsidótörvények alapján indított eljárások megindításában, foganatosításában, a diszkriminatív joggyakorlat megvalósításában? Leszúkítettem az időhatárt, amelynek a magyarázata az, hogy 1944-re már mind a huszonegy zsidótörvény és a hozzájuk kapcsolódó rendeletek jelentős része hatályban volt, és ekkorra részévé váltak a bíróságok joggyakorlatának is. A zsidótörvények mellett pedig a korszak egyéb ,jellegzetes” bűncselekményeiről is képet kaphatunk, mint például a honvédelem körében elkövetett cselekményekről.

A tanulmány mindezek alapján három részre oszlik. Az első részben a rendelkezésre álló szakirodalmat és a forrásokat tekintem át, a második részben a Miskolci Királyi Törvényszék elött zajló büntetőperek jellegzetességeit mutatom be, és végül a zsidótörvényekkel kapcsolatos perekkel foglalkozom.

\section{Szakirodalom és az elsődleges források}

A két világháború magyarországi közötti bírósági joggyakorlatra vonatkozó kutatások, statisztikai adatok léteznek, ezek azonban nem teljeskörűek, mivel a Horthy-korszak büntető anyagi és eljárásjoga - ahogy fentebb említettem - még nagyrészt feltáratlan területe a jogtörténetnek. A zsidótörvényekkel összefüggő bírósági eljárások egy-egy területére terjednek ki a statisztikai adatok és a kutatások, így elsősorban a fajgyalázási perekre, valamint a zsidótörvény kijátszásával összefüggő esetekre. Történeti, társadalomtörténeti, jogtörténeti megközelítéseket is találunk a szakirodalomban. Főleg a fajgyalázási perekre utal több szerző is, így például Sz̨ita Szabolcs, ${ }^{10}$ Karsai

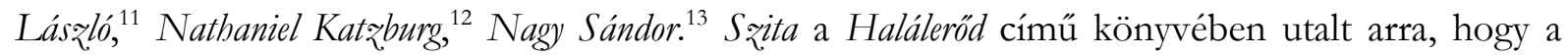
fajgyalázás mellett jelentôs számban megnövekedett a zsidók ellen többféle ürüggyel indított, zömében „koholt perek” száma, részletesen azonban nem foglalkozott ezeknek az ügyeknek a

\footnotetext{
${ }^{7}$ Reiter-Zatloukal, Der Bundesgerichtshof 1934-1938; Idem, „... um alles nazistische Tätigkeit und Propaganda in Österreich zu verhindern“. NS-Wiederbetätigung im Spiegel von Verbotsgesetz und Verwaltungsstrafrecht; Idem, Die Umgestaltung der österreichischen Strafrechtsordnung im NS-Staat; Idem, Antisemitismus in Österreich 1933-1938; Idem, Richterbild und Richterausbildung im nationalsozialistischen Deutschen Reich.

${ }^{8}$ SCHMitzBerger: Das Nationalsozialistische Nebenstrafrecht 1933 bis 1945.

9 A témáról lásd részletesen LEHOTAY, Szabadságjogmegvonó intézkedések a Horthy-korszakban, különös tekintettel a zsidótörvényekre.

${ }^{10}$ SZITA, Halálerőd.

${ }^{11}$ KARSAI, A magyarországi zsidótörvények és rendeletek 140-163.

${ }^{12}$ KATZBURG, Zsidópolitika Magyarországon 153-162.

${ }^{13} \mathrm{NAGY}$, A fajvédelem útvesztőjében 487-588.
} 
bemutatásával. ${ }^{14}$ Karsai Lásそ̨ó a fajgyalázási perekkel kapcsolatban azt emelte ki, hogy az eddigi kutatások alapján rendkívül ritkák ilyen esetek. ${ }^{15}$ A fajgyalázási perek társadalomtörténeti

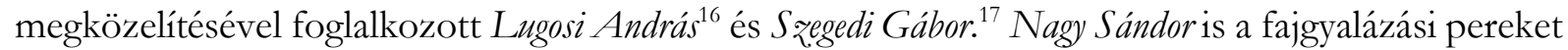
vizsgálta $A$ fajvédelem útvesżőjében címû tanulmányában. Ô egyrészt azt rögzítette, hogy a történészek döntő többsége egyetért azzal, hogy a harmadik zsidótörvény házasságon kívüli zsidó-keresztény nemi viszonyra, fajgyalázásra vonatkozó 15. szakaszát a gyakorlatban nem, vagy csak elvétve alkalmazták, másrészt viszont rámutatott arra is, ahogyan ő fogalmaz: „... a kép ettől összetettebb és mindenképpen árnyaltabb”. ${ }^{18}$ Különbség van szerinte a büntető igazságszolgáltatás különböző szintjeinek múködését, ügyforgalmát jelző adatok között városi és vidéki szinten. Míg vidéken viszonylag ritkán került sor fajgyalázás miatt indított büntetőeljárásra, addig Budapesten (ahol a zsidóság kétharmada élt) jelentős számú ilyen esetre került sor. Ugyanakkor rögzíthetô az is, hogy jogászi szemszögből a városi és vidéki szint megkülönböztetése az igazságszolgáltatásban nem helytálló, hiszen különbség van a bírósági szervezet más-más szintjén és fokán indult eljárások között. Nagy statisztikai adatokat is közölt: országos statisztika csak az 1942-ben jogerősen befejezett fajgyalázási ügyekrôl készült, eszerint viszont ebben az évben nem kevesebb mint 707 alkalommal tettek feljelentést ,fajvédelmi törvénybe ütközó büntett” miatt. ${ }^{19}$ Ezek közül 605 esetben az eljárás nem jutott bírói szakaszba; a törvényszékek 102 ilyen pert tárgyaltak; 61 esetben hoztak marasztaló, 41 alkalommal pedig felmentő ítéletet. ${ }^{20}$ Ezekből az adatokból az nem derül ki, hogy mely bíróságokon indultak az eljárások. Antal Tamás 2019-ben megjelent kétkötetes monográfiájában a Kúria történetét mutatta be, ${ }^{21}$ azonban az alsóbb bíróságok joggyakorlatának teljeskörű feltárása még várat magára.

A tanulmány forrásbázisát a levéltári dokumentumok alkotják. Az 1938 és 1944 közötti időszakban a Miskolci (Királyi Ügyészség) Államügyészség iratai szerint a rendelkezésre álló levéltári lista alapján összesen 3279 ügyre került sor, amelyből mindössze huszonhárom zsidótörvénnyel kapcsolatos eljárás, amelyek közül mindössze huszonhárom zsidótörvénnyel kapcsolatos eljárást találtam. A Miskolci Királyi Törvényszék két világháború közötti tevékenységének a kutatására még nem került sor. Borsod-Abaúj-Zemplén Megyei Levéltár alsózsolcai részlegében a Miskolci Királyi Törvényszékre vonatkozó iratok jelentôs része megmaradt és kutatható. Arra vonatkozóan sajnos nincs adat, hogy összesen hány eljárásra került sor a vizsgált idôszakban, mert több dobozban kevesebb per található, mint amennyi rá van írva. ${ }^{22}$ 1938 és 1944 között harminc doboz tartalmazza a törvényszéki iratokat, amelyeknek jelentős része 1944-ből származik. Találhatók az iratok között Mintadarad. Nem selejtę̧hetó! feliratú dokumentumok is. Nyilván ebből következik, hogy több ilyen perre került sor, csak az iratokat időközben selejtezték. Az azonban elmondható, hogy az eljárások döntő többségét (mintegy nyolcvan

\footnotetext{
14 SZITA, Halálerőd 15.

15 KARSAI, A magyarországi zsidótörvények és rendeletek 1302.

${ }^{16}$ LUGOSI, „Sztalin föhercege” 527-576.

${ }^{17}$ SZEGEDI, Good Health is the Best Dowry 307-317.

${ }^{18}$ NAGY, A fajvédelem útvesztőjében 488.

${ }^{19}$ NAGY, A fajvédelem útvesztőjében 488.

${ }^{20}$ NAGY, A fajvédelem útvesztőjében 488.

${ }^{21}$ ANTAL, Az Igazságügyminisztérium története 1867-1944.

221938 és 1944 között 30 doboz tartalmazza a törvényszéki iratokat, amelyeknek jelentős része, összesen 141 per 1944 ből származik. A dobozok vegyesen tartalmazzák a büntető és a polgári perek iratait vegyes évkörű iratok jelzéssel.
} 
százalékát) a büntetőperek teszik ki. A polgári perek között főleg kisajátítási, hűtlen elhagyási, és váltóval kapcsolatos periratok találhatók. A korabeli szaksajtóban (Büntetőjog Tára, Jogtudományi Közlöny, Jogállam, Igazságügyi Közöny) is számos esetben találkozunk bûncselekmények elemzésével, perek bemutatásával. Mindemellett az országos és a helyi sajtó (Felsőmagyarországi Hírlap, Miskolci Napló) is folyamatosan közölte a Miskolci Királyi Törvényszék előtt lezajlott érdekesebbnek tekintett pereket, amelyek között találunk lopást, nemzetgyalázást, sikkasztást, fajgyalázást is. Ezeknek a sajtóanyagoknak a vizsgálata azért is érdekes, mert számos olyan perről adnak hírt, amelyek viszont a levéltári források között nem találhatók.

Milyen bűncselekmények miatt indultak eljárások? A büntetôperek között megtalálhatóak a „szokásos” bűncselekmények miatt zajló perek, így a lopás, a gyújtogatás, az okirathamisítás, az izgatás szerepelt vádként a dokumentumokban. A legnagyobb számban a vagyon elleni bűncselekményeket találjuk. Ez azzal magyarázható, hogy az ellátási nehézségek növekedése és az áruhiány miatt jelentősen megnőtt a lopások száma. Az ügyészségek utasítást kaptak, hogy ezeknél a cselekményeknél mindig a szigorúbb álláspontot képviseljék, és ennek figyelembevételével folytassák le a nyomozást és lássák el a vád képviseletét. Jelentôs többletfeladatot jelentettek a Miskolci Királyi Törvényszék számára is az új, addig ismeretlen bűncselekmények miatt indított ügyekben való eljárások, így például a nemzetgyalázás, kormányzósértés, honvédelem elleni izgatás, fegyveres erő elleni izgatás, izgató nyomtatványok terjesztése, állam és társadalom elleni vétség, valótlanhír-terjesztés, tiltott sajtótermék terjesztése, nemzet megbecsülése elleni vétség miatt indított pereket is.

\section{Büntetőperek 1944-ben a Miskolci Királyi Törvényszék előtt}

A két világháború közötti büntetőjog alakulását a tettesbüntetőjogi irányzat tanainak a megerősödése jellemezte. ${ }^{23} \mathrm{~A}$ modern büntetőjog képviselői egyre inkább azt az elméletet fogadták el, amely szerint nem az elkövetett bűncselekményért kell a tettest megbüntetni, hanem bizonyos társadalomra veszélyes tulajdonságai miatt. Így például azért, mert szélhámos, közveszélyes vagy csavargó. ${ }^{24} \mathrm{~A}$ korszakban több olyan jogszabály született, amely olyan különleges jogkört biztosított az állam számára, hogy annak védelmére hivatkozással az állampolgárok jogainak a korlátozására több ízben sor került. ${ }^{25} \mathrm{Az}$ állam elleni bűncselekmények körében a Csemegi-kódex (1878. évi V. tc.) a felségsértést, a hútlenséget és a lázadást szabályozta.

Majd a korszak kezdetén született a rendtörvény. Az 1921. évi III. törvénycikk az állami és társadalmi rend védelmét szolgálta a felforgatókkal szemben, és szakított a Csemegi-kódex liberális felfogásával. Az ún. rendtörvény elméleti magyarázata az volt, hogy ha az állam és a társadalom rendje megbomlik, akkor nincs biztonságban az élet, a testi épség és a vagyon sem. Az 1941. évi V. törvénycikk ${ }^{26}$ pedig hat hónapig terjedő fogházbüntetést helyezett kilátásba vétség miatt abban az esetben, ha valaki az országban élő nemzetiségre lealacsonyító kifejezést használt, és ezzel megsértette nemzetiségi érzületét. Ezekben az esetekben a háborúellenes, a kormány intézkedéseit kifogásoló kijelentések miatt nemzetgyalázás, valótlan hír terjesztése, izgatás, kormányzósértés

\footnotetext{
${ }^{23}$ KABÓDY - MEZEY, Büntetési elméletek 53-64.

24 KoTEK - RigOulot, Táborok évszázada 250.

${ }^{25}$ KOCSIS, A magyar állam büntetőjogi védelmének törvényi szabályozása 91.

26 1941. évi V. törvénycikk a nemzetiségi érzület védelméről.
} 
miatt indultak az eljárások. A következőkben az egyes búncselekmények, bűncselekménycsoportok gyakorlatát vizsgálom a Miskolci Királyi Törvényszéken a következő felosztás szerint: magyar állam-és nemzet ellen irányuló bűncselekmények, honvédelem elleni bűncselekmények, az élet- és testi épség elleni bűncselekmények, vagyon elleni bűncselekmények, gazdasági büncselekmények.

Milyen adatok derülnek ki a Miskolci Királyi Törvényszék 1944-es dokumentumaiból? A 63 éves, izraelita vallású, férjes, gyermektelen $G$. Józsefné három ember elótt azt a kijelentést tette, hogy „...majd eljön az idó, amikor a zsidóság duplán visszaadja a magyaroknak ąt, amit azok tettek a sæidókkal”. ${ }^{27}$ A Kassai Királyi Ügyészség elé került az ügy, amely vádként az állam és társadalmi rend felforgatására irányuló izgatást határozta meg. Azonban ezt a vádat megváltoztatta valótlan hír terjesztésére, mivel a kijelentést alkalmasnak találta arra, hogy a magyar állam megbecsülését csorbítsa és hitelét sértse. Az elkövetési helyre (Bánhorváti) és arra tekintettel, hogy „... az ügy jelentösége nem olyan nagy, hogy a közérdek szempontjából az öt tagú külön tanács elé vitele mutatkoznéke. szüleségesnek", 28 áttette az ügyet a miskolci ügyészsége. Így a terhelt ellen a rendtörvény 7. szakaszába ütköző magyar állam és nemzet megbecsülése ellen irányuló vétség miatt indult eljárás 1944-ben. A Miskolci Királyi Törvényszék 1944. május 23-án jogerősen főbüntetésként két hónap fogházbüntetésre, és mellékbüntetésként három évi hivatalvesztésre és politikai jogok gyakorlásának a felfüggesztésére ítélte G. Józsefnét. A csendőrségi iratok tanúskodnak arról, hogy 1944. június 1-jén a sajószentpéteri gettóba szállították az elítéltet, majd az őrs tudomása szerint „...onnan továbbitva lettek. Tartózkodási helye ismeretlen”. ${ }^{29}$ Itt tehát zsidónak minôsülő személlyel szemben jogerős marasztaló ítéletet hozott a törvényszék - bár nem a zsidótörvények alapján -, amelyet azonban a gettóba zárás, majd a deportálás miatt nem hajtottak végre.

A honvédelem elleni bűncselekmények körét kétszer is módosították, így 1930-ban a katonai büntető törvénykönyvvel és 1939-ben a honvédelmi törvénnyel. A katonai büntetô törvénykönyv megalkotására azért került sor, mert a régi katonai büntetőkódex elavult volt és szabályai nem voltak összhangban a Csemegi-kódexszel. Ezt úgy valósította meg a jogalkotó, hogy a katonákra is általában a Btk. rendelkezéseit kellett alkalmazni, de a törvény meghatározott különleges katonai bűncselekményeket is. A jogszabály külön „tiszti becsületet” ismert el azzal a rendelkezéssel, mely büntetlenséget biztosított annak a katonai egyenruhát viselő tiszt(jelölt)nek, aki „a becsülete ellen más személy jelenlétében intézett jogtalan támadás folytatásának megakadályozása céjából az. ôt megilletö fegyvert azonnal használja”. ${ }^{30}$ Utóbbi jogszabály meghatározta a leventekötelezettséggel, a hadkötelezettséggel, a közérdekű munkaszolgálattal és a légvédelmi kötelezettséggel összefüggő bűncselekmények körét. Ismeretlen tettes ellen indult eljárás a honvédelmi törvényben foglalt sajtórendészeti vétség, konkréten röpirat szerkesztése miatt. ${ }^{31}$ A röpirat azt a mondatot tartalmazta, „... hogy bát még ma is ülhet zsidó miniszteri székebe”. ${ }^{2}$ A röpcédulát lefoglalták, de az elkövetôt nem

\footnotetext{
${ }^{27}$ MNL BAZM VII-1/b. 146/1944. szám.

${ }^{28}$ MNL BAZM VII-1/b. 146/1944. szám.

${ }^{29}$ MNL BAZM VII-1/b. 146/1944. szám.

${ }^{30}$ A jogszabály szerint ez a fegyverhasználat csak abban az esetben nem volt beszámítható az elkövető tisztnek, ha ,ęt a célt másként nem érhette el (...) a fegyver használatában az elkerülhetetlen szülkségesség határát nem lépte át”. 1930. évi II. törvénycikk a katonai büntetőtörvénykönyvről. Lásd még: KOVÁCS, A magyar büntetőjog és büntetőeljárási jog története 33 .

31 1939. évi II. törvénycikk a honvédelemről. MNL BAZM VII-1/b. 500/1944. szám.

32 MNL BAZM VII-1/b. 500/1944. szám.
} 
találták meg, így megszüntették az eljárást. Ebben az esetben nem a jogkorlátozáshoz kapcsolódó ügyről van szó, sőt, amennyiben tartalmilag vizsgáljuk meg ezt a az ügyet, akkor láthatjuk, hogy védelmet fejez ki azáltal, hogy eljárás indul olyasvalaki ellen, aki negatív értelemben használja valakire a zsidó megjelölést.

Az élet és testi épség elleni cselekmények számában viszont javulást következett be, melynek okát az ügyészek a katonai munkaszolgálatra behívásokban látták, mivel így az „...az emberek el lettek vonva a veszekedésekböl, a korcsmákból, mert ennek következménye szokott lenni az ilyen".33 Az élet és testi épség elleni bűncselekmények köréből a magzatelhajtásokat és az öngyilkossággal összefüggő eljárásokat emelem ki. Dr. K. József öngyilkossága ${ }^{34}$ ügyében indult eljárás az 1896. évi XXXIII. törvénycikk, a Bűnvádi Perrendtartás 101. szakaszának 1. pontja alapján - mely szerint az eljárást bűncselekmény hiányában meg kell szüntetni - került megszüntetésre. Bủncselekmény tényállása nem forgott fenn a nyomozás adatai alapján. V. Gabriella lúgkő ivásával öngyilkossági kísérletet követett el 1944-ben, miután teherbe esett és a szülei nem tudták biztosítani számára a hozományt a házasságkötéshez. Hivatalból indult eljárás ismeretlen tettes ellen, öngyilkosságra való rábírás miatt. A bizonyítékok hiányában azonban az eljárás megszűnt. A tanúként kihallgatott vőlegény pedig előadta, hogy a lányt feleségül veszi a hozomány nélkül is. ${ }^{35} Z$. Gáspár 1942 júliusától 1943 májusáig az orosz fronton volt, amelynek következtében a tanúvallomások alapján az idegei tönkrementek és a családja és önmaga elpusztításával fenyegetőzött. Végül felakasztotta magát. Az eljárási törvény 101. szakasz 1 . paragrafusa alapján az eljárás megszűnt. ${ }^{36} \mathrm{~A}$ magzatelhajtások körében a 22 éves, háztartásbeli O. Borbála ellen indult eljárás, mert 1943 decemberében hat hónapos magzatát elvetélte. ${ }^{37}$ Elegendő bizonyíték a vádemeléshez nem volt, így megszűnt az eljárás 1944. január 21 -én. Névtelen feljelentés alapján indult eljárás D. Dezső́né ellen magzatelhajtás miatt, 1944. március $27-e ́ n$ azonban a bizonyítékok hiányában megszüntették ellene a nyomozást. ${ }^{38}$ Mindkét bűncselekményi kategória esetében elmondható, hogy ezek az eljárások a legtöbbször még a főtárgyalás előtt végett értek bizonyítékok hiányában.

A vagyon elleni bűncselekmények körében jelentős számban fordultak elő lopások. Özvegy K. Jenöné, K. Magdolna, K. Klára, Gy. Ferencné mezőcsáti lakosok ellen lopás bűntette miatt indult eljárás, mert 1943-ban Mezőcsáton több alkalommal, de egy akaratelhatározásból S. Ferenc sértettől (akinél K. Magdolna, az egyik vádlott alkalmazásban állt) ${ }^{39}$, annak beleegyezése nélkül jogtalanul eltulajdonítottak 200 pengőn felüli, nagyobb ingóságokat. 1944. március 11-én bizonyítékok elégtelensége folytán másodfokon felmentő ítélet született. Meglehetősen hiányosak az iratok, így például az elsőfokú ítélet sem maradt fenn. Ez a per azért is érdekes, mert 1944-ben történt és a vádlottak izraelita vallásúak voltak, tehát a már hatályban lévő diszkriminatív zsidótörvények vonatkoztak rájuk, ugyanakkor a bíróság felmentő ítéletet hozott. ${ }^{40}$ A Miskolci Királyi Törvényszék előtt viszonylag jelentôs számú perre került sor fiatalkorú elkövetők ellen főleg lopás és testi sértés

\footnotetext{
33 VERESS, Erdély jogtörténete 442.

34 MNL BAZM VII-1/b. 58/1944.

35 MNL BAZM VII-1/b. 213/1944. szám.

36 MNL BAZM VII-1/b. 237/1944. szám.

${ }^{37}$ MNL BAZM VII-1/b. 248/1944. szám.

38 MNL BAZM VII-1/b. 294/1944. szám.

39 1878. évi V. tc. 336. \ 7. pontja értelmében tekintet nélkül a lopott dolog értékére, bűntettet képez a lopás, ha: 7. szolgálatban álló személy azon, kinek szolgálatában áll, vagy annak házához tartozó személyen követi el.

40 MNL BAZM VII-1/b. 361/1944. szám.
} 
miatt. Például K. István 14 éves fiatalkorú, szalonnai lakos és édesanyja, K. Rudolfné (31 éves, római katolikus napszámos) tettestársak ellen lopás bűntette miatt az Edelényi Királyi Törvényszéken került sor a tárgyalásra 1944-ben. A tényállás szerint 1944-ben közösen a sértett zárt padlásáról 14 $\mathrm{kg}$ vegyes babot tulajdonítottak el 11 pengő értékben. Ebben az eljárásban a hátrányos következmények elkerülése érdekében a fiatalkorú és a felnőttkorú vádlott cselekményét ugyanaz a bíróság bírálta el. ${ }^{41}$

A gazdasági bűncselekmények körében az árdrágítási és a közellátás érdekeit érintő bűncselekmények egyre növekvő száma jelentős mértékben befolyásolta az ügyforgalmat országos szinten, és a Miskolci Királyi Törvényszéken is. A jogalkotó több rendelkezést is kiadott a „...közérdek szempontjait semmibe vevô üzérkedések” kezelésére azzal az indokolással, hogy ezek a cselekmények sértik az állam biztonságát és rontják a pengő vásárlóértékét. ${ }^{42}$ Fontos volt ezért ezeknél a bűncselekményeknél a visszatartó hatású büntetéseknek a kiszabása, így a pénzbüntetés és a szabadságvesztés mellett a terhelt egész vagyonára kiterjedő elkobzás, az iparigazolványtól, engedélytől, tevékenységtől való eltiltást is alkalmazni kellett. Az árdrágító visszaéléseket 1920-ban szabályozta törvény. ${ }^{43} \mathrm{~A}$ jogszabály az írdrágító visszaélések nyolc tényállását határozta meg, többek között az ár túllépést, az árdrágító üzérkedést, az áruelvonást, az árcsempészetet, a közszükségleti cikkek eladásának megtagadását. A közszükségleti cikk fogalmát a törvény nem határozta meg, azt a bírói gyakorlat alakította ki. Közszükségleti cikk jogellenes elvonásának bűntette miatt, az 1939. évi II. törvénycikk 206. szakasza alapján indult eljárás több terhelt ellen 1944-ben, akik közül többen izraelita vallásúak (E. Lajos, mészáros, W. Jenố) voltak. ${ }^{44}$ A tényállás szerint 2000 pengőt meghaladó értékű 99 darab szarvasmarhát jogellenesen elvontak és engedély nélkül levágtak. A szarvasmarhákkal való szabad rendelkezést korábban kormányrendelet korlátozta. A főtárgyalásra 1944. október 16-án került sor. Sajnos a dokumentumok hiányosak, az eljárás végéről nem maradtak fenn iratok. Tekintettel a dátumra ${ }^{45}$ feltehető, hogy nem került sor a tárgyalásra. Másrészt ekkora már a vidéki zsidóság deportálása megtörtént, tehát a vádlottakat valószínúleg már elhurcolták. A tanulmány utolsó részében azt vizsgálom, hogy milyen zsidótörvényekkel kapcsolatos eljárásokra került még sor a Miskolci Királyi Törvényszéken.

\section{Diszkriminatív joggyakorlat? A zsidótörvények alapján indított perek a Miskolci Királyi Törvényszék elött}

A zsidótörvények és büntetőjog összefüggését a kor neves büntetőjogásza, Angyal Pál vizsgálta részletesen 1938-ban, és rögzítette, hogy a „fajvédelemnek” nem lehet szerepe a büntetőjogban. ${ }^{46}$ Úgy foglalt állást, hogy a büntetőjogi védelem csak meghatározott jogtárgyakra terjedhet ki, és úgy

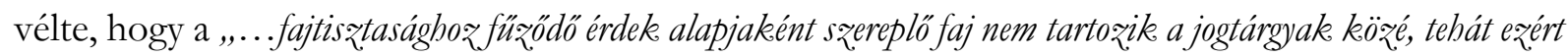
büntetöjogi védelemben sem lehet részesiteni. ${ }^{47} \mathrm{~A}$ zsidótörvényekbe ütköző bűncselekményekkel

\footnotetext{
41 MNL BAZM VII-1/b. 504/1944. szám.

42 Például az 1941. évi X. törvénycikk a közellátás érdekét veszélyeztető cselekmények büntetéséről.

43 1920. évi XV. törvénycikk az árdrágító visszaélésekről.

44 MNL BAZM VII-1/b. 3212/1944. szám.

45 Horthy Miklós lemondása, nyilas hatalomátvétel.

46 ANGYAL, Fajvédelem és büntetőjog 6.

47 ANGYAL, Fajvédelem és büntetőjog 6 .
} 
kapcsolatban a csendőrség számára készült kézikönyv szerzői eltekintettek a zsidótörvények által szabályozott bűncselekmények részletes ismertetésétôl, és azt az utasítást írták elő a csendőr számára, hogy ilyen bűncselekmény gyanúja esetén a „...sžerzett értesülését vagy az örsön tett panaszfeljelentést" érdemleges nyomozás nélkül továbbítsa az ügyészségnek. ${ }^{48}$ Ezt pedig azzal indokolták, hogy ezeknek a bűncselekményeknek a nyomozása „rendkiviul szövevényes” és meghaladja a csendőr hatáskörét. ${ }^{49} \mathrm{~A}$ büntetőjogi szabályok értelmezésében fontos szerep jutott a kúriai joggyakorlatnak is.

A bűncselekmények között a témánk szempontjából azok a legfontosabbak, amelyekben zsidónak minősülő személy szerepel elkövetőként, sértettként vagy tanúként. Hogyan ítélte meg a Miskolci Királyi Törvényszék ezeket a helyzeteket? Másképpen fogalmazva például találunk-e olyan esetet, amelyben a terhelt zsidónak minősülő személy, és vonatkoznak rá a szidótörvények, ugyanakkor a Miskolci Királyi Törvényszék felmentő itéletet hozott az esetében?

A második zsidótörvény (1939. évi IV. törvénycikk) ${ }^{50}$ alapján, ahogyan az iratokon szerepel

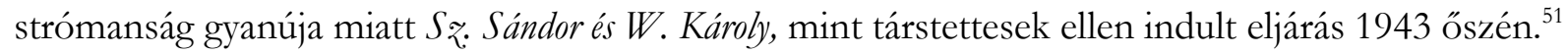
A vádak között szerepelt az 1922. évi III. törvénycikk 39. szakaszába ütköző kihágás, zsidóbújtatás vétsége, és a 1939. évi IV. törvénycikk 26. szakaszának 6. paragrafusába ütköző vétség is. A tényállás

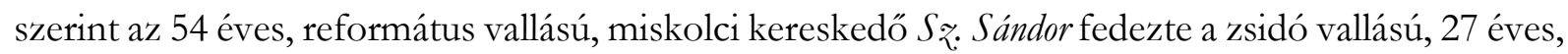
volt kereskedő $W$. Károly jogosulatlan kereskedelmi tevékenységét. 1941-ben a zsidótörvény

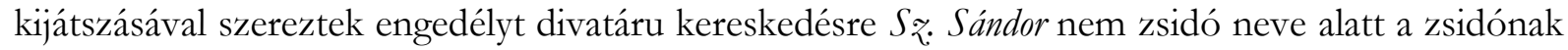
minkősülő $W$. Károly részére. A vádemelésre 1944 októberében került sor. A terheltek tagadták a cselekmény elkövetését, védekezésük szerint a tulajdonos $S_{\text {}}$. Sándor volt, $W$. Károly pedig az ő alkalmazottja. Az iratok szerint több zsidónak minősülő személy is alkalmazásban volt a kereskedésbe. Tárgyalásról nincsenek dokumentumok, feltehető, hogy nem került rá sor. 1945. június 22-én a Miskolci Királyi Ügyészség indítványozta a Miskolci Királyi Törvényszéknél az eljárás megszüntetését a 200/1945. ME rendelet alapján. ${ }^{52}$ Ez a jogszabály a zsidótörvények és a rendeletek hatályon kívül helyezéséről rendelkezett. A Miskolci Királyi Törvényszék a végzést 1945 nyarán hozta meg, amelyben tárgyaláson kívüli vádelejtés miatt megszüntette az eljárást. Még egy értesítési irat maradt fenn, amely arról tanúskodik, hogy W. Sándornak Miskolcon bejelentett lakása 1945 nyarán nem volt. Számára tehát az eljárás megszüntetéséről szóló értesítést kézbesíteni nem tudták. $^{53}$

R. Margit izraelita terhelt ellen a Büntetőtörvénykönyv 400. szakasza szerinti közokirathamisitás miatt indult eljárás. ${ }^{54}$ A tényállás szerint jogtalan haszonszerzés céljából a cselédkönyvbe és a Főszolgabírói Hivatal által vezetett lajstromba a jogviszonyára vonatkozó valótlan tényeket vezetett be. S. Sándor munkaszolgálatos zsidót kérte meg, hogy szerezzen számára cselédkönyvet, hogy megmenthesse az életét. A terhelt a cselekmény elkövetését beismerte, védelmére előadta, hogy a zsidókat érintő rendeletek kijátszása céljából váltott hamis cselédkönyvet.

\footnotetext{
${ }^{48}$ KISZELY, Mondd el fiaidnak 7.

49 MiskolCZY - PINCZÉS, A magyar büntetőjog gyakorlati kézikönyve 1139.

50 1939. évi IV. törvénycikk a zsidók közéleti és gazdasági térfoglalásának korlátozásáról.

51 MNL BAZM VII-1/b. 4405/1944. szám.

52 MNL BAZM VII-1/b. 4405/1944. szám.

${ }^{53}$ MNL BAZM VII-1/b. 4405/1944. szám.

${ }^{54}$ MNL BAZM VII-1/b. 4195/1944. szám.
} 
Elrendelték az előzetes letartóztatását, majd a vizsgálóbíró 1944. április 25-én ezt megszüntette. Indokolásában az szerepelt, hogy szökéstől nem kell tartani és a terhelt rendes lakással rendelkezik. A bűnjeljeleknek, a cselédkönyvnek és a vásárlási könyvnek a novemberi háborús események következtében elveszett. 1944 novemberében keletkezett irat szerint az ügyészség a törvényszékhez tette át a cselédkönyvet. 1945 januárjában vádiratról szóló értesítés nem volt kézbesíthető. 1945 januárjában az eljárási törvény 472. szakaszának 4. bekezdése alapján a távollévő, ismeretlen helyen tartózkodó terhelttel szemben a terhelt előállításáig a bűnvádi eljárás megszüntetésére került sor. Az iraton szerepel egy 1950-es dátum is és egy felirat: „A zsidó ügyek. jegyzékébe bevezetendô”. ${ }^{5} 1949$. március 17-én kelt irat szerint a bűnjelek előkerültek, és azokat az iratokhoz csatolták. Ebben az esetben nem a zsidótörvények alapján indított eljárásról van szó tehát, hanem a zsidótörvények, és a német megszállás után megalkotott jogfosztó rendeletek kijátszásáról. R. Margit a meghamisított cselédkönyvvel próbált menekülni a jogfosztástól, amely ekkor már a gettósítást és a deportálást jelentette. Tárgyalásra nem került sor, hiszen ekkora már valószínúleg deportálták R. Margitot, viszont még 1949-ben is foglalkoztak ezzel az üggyel. ${ }^{56}$ R. Margit sorsáról sajnos további információk nem állnak rendelkezésemre. Ez a törvényszéki iratokon túli, további kutatást igényelne.

\section{Záró gondolatok}

Összegzésként rögzíthetjük, hogy a Miskolci Királyi Törvényszék dokumentumainak vizsgálata a következőkre mutat rá. Elsőként, hogy a dokumentumok sokszor hiányosak, így több esetben nem derült fény az eljárás eredményére. Ennek oka lehet, hogy az iratok megsemmisültek, de elképzelhetô az is, hogy a háborús események és a deportálások miatt nem is folytatódtak az eljárások. Ugyanakkor több dokumentum tanúskodik arról, hogy még a háborút követően is foglalkoztak a lezáratlan eljárásokkal. Másodikként elmondható, hogy jelentősen megnövekedett a magyar állam és nemzet megbecsülése ellen irányuló vétségek, a valótlan hír terjesztése, a honvédelem elleni izgatás miatt indított eljárások száma, amelyek jelentős része marasztaló ítélettel zárult. Harmadikként látható, hogy a családi viszonyok meglazulása következtében országos és helyi szinten is megnövekedett a magzatelhajtások száma, és ezek a bűncselekmények kiemelt figyelmet kaptak. A hatóságoknak fokozottan figyelemmel kellett kísérnie a vetélési eseteket, a szülésznők és az orvosok tevékenységét. Ez a tendencia tehát a Miskolci Királyi Törvényszéken is megfigyelhető. Azonban döntő részük már a nyomozati szakban megszüntetésre került. A vetélő nő tagadásával szemben ugyanis általában nem voltak megfelelő bizonyítékok a vádemeléshez. Végül a zsidótörvényekkel kapcsolatos perek esetében a kutatás igazolja Nagy Sándornak azt a megállapítását, hogy vidéken viszonylag kevés zsidótörvénnyel összefüggő per indult. Zsidótörvénybe ütköző vétség miatt kettő, míg a zsidótörvény kijátszása miatti közokirathamisítás miatt egy eljárás indult. Fajgyalázás miatt összesen négy per zajlott, amelyből kettőre 1943-ban, és kettőre 1944-ben került sor. Sok esetben már az ügyészségi szakban megszüntették az eljárást a bizonyítékok hiánya miatt. Kellő bizonyítékok megléte esetén pedig a deportálások miatt nem került sor az eljárás további

\footnotetext{
${ }^{55}$ MNL BAZM VII-1/b. 4195/1944. szám.

${ }^{56}$ MNL BAZM VII-1/b. 4195/1944. szám.
} 
szakaszaira. Teljes képet a további évek dokumentumainak a feltárásával kaphatunk majd, ami a kutatás következô lépése.

A Miskolci Királyi Törvényszék (1944-ben zajlott) büntetôpereinek a vizsgálatai (is) árnyalhatja Bibó Istvánnak azt a gondolatát, mely szerint: „Odáig csak nagyon kevesen jutottak el, hogy az. állambatalmat gengszterbandának, rendeleteit papirrafatoknak, s a velïk szemben való engedetlenséget, kijátszást és hamisitást erkölcsi kötelességüknek tekintsék.". ${ }^{57}$

\section{Felhasznált irodalom és források}

ANGYAL Pál: Fajvédelem és büntetőjog. Budapest 1938

ANTAL Tamás: Az Igazságügyminisztérium története 1867-1944. Fejezetek a polgári kor évtizedeiből. Budapest 2019 BERÁNNÉ NEMES Éva - RomÁN János: Miskolc története. Borsodi Történelmi Évkönyv. 5/1. IV. kötet. Miskolc 1981 BIBÓ István: Válogatott tanulmányok 1945-1949. Budapest 1986

CsIZMAdiA Andor - KovÁcs Kálmán - AszTALOs László: Magyar állam-és jogtörténet. Budapest 1998

ECKHARDT Ferenc: Magyar alkotmány-és jogtörténet. Budapest 2000

FORM, Wolfgang: Literatur- und Urteilsverzeichnis zum politischen NS-Strafrechts. Baden-Baden 2001

KABÓDy Csaba - MEZEY Barna: Büntetési elméletek. Módszertani Füzetek 1985/4. sz. 53-64.

KARSAI László: A magyarországi zsidótörvények és rendeletek 1920-1944. In: MOLNÁR Judit (szerk.): A holokauszt Magyarországon európai perspektívában. Budapest 2005, 140-163.

KATZBURG, Nathaniel: Zsidópolitika Magyarországon 1919-1943. 2002 Budapest

KISZELY Gábor: Mondd el fiaidnak! A holokauszt és Magyarország. Budapest 2005

KOCSIS Zsolt László: A magyar állam büntetőjogi védelmének törvényi szabályozása 1878 és 1944 között (a dualizmustól a Horthy-rendszer időszakáig). Budapest 2007

KoTEK, Joel - Rigoulot, Pierre: Táborok évszázada. Budapest 2000

KovÁCs Kálmán: A magyar büntetőjog és büntetőeljárási jog története 1848-tól 1944-ig. Budapest 1971

LEHOTAY Veronika: Szabadságjog-megvonó intézkedések a Horthy-korszakban, különös tekintettel a zsidótörvényekre. PhD-értekezés. Miskolc 2013 http://www.uni-miskolc.hu/ wwwdeak/lehotayv_ertmh.pdf (2018. 06. 29.)

LUGOSI András: „Sztalin főhercege”. Kohn báró vacsorái a Falk Miksa utcában a fajgyalázási törvény idején. Fons 2010/4. sz. 527-576.

MNL BAZM = Magyar Nemzeti Levéltár Borsod-Abaúj-Zemplén Megyei Levéltára. VII. 51/b. A Miskolci (Királyi Ügyészség) Államügyészség iratai. 1938-1944 és VII-1/b. A Miskolci Királyi Törvényszék iratai 1938-1944

MisKolCZY Ágost - PINCZÉs Zoltán: A magyar büntetőjog gyakorlati kézikönyve M. Kir. Csendőrség számára, I. kötet. Budapest 1940

NAGY Sándor: A fajvédelem útvesztőjében. Bírói gyakorlat „fajgyalázási perekben” (1942-1944). Fons. 2015/4. sz. 487-532.

ReIter-Zatloukal, Ilse: „,.. um alles nazistische Tätigkeit und Propaganda in Österreich zu verhindern“. NS-

Wiederbetätigung im Spiegel von Verbotsgesetz und Verwaltungsstrafrech. Graz 2018

Reiter-Zatloukal, Ilse: Antisemitismus in Österreich 1933-1938. Wien 2018

Reiter-Zatloukal, Ilse: Der Bundesgerichtshof 1934-1938. Wien 2013

REITER-ZATLOUKAL, Ilse: Die Umgestaltung der österreichischen Strafrechtsordnung im NS-

Staat. Österreichische Richterzeitung 92 (2014) 145-151.

REITER-ZATLOUKAL, Ilse: Richterbild und Richterausbildung im nationalsozialistischen Deutschen Reich. Wien 2014 SAMU Mihály - BARABÁS Alice - TAKÁCS Imre - NAGY László: Tanulmányok a Horthy-korszak államáról és jogáról. Budapest 1958

SCHMtTZBERGER, Johanna: Das Nationalsozialistische Nebenstrafrecht 1933 bis 1945. Salzburg 2007

\footnotetext{
${ }^{57}$ BIBÓ, Válogatott tanulmányok 638.
} 
SCHWEITZER Gábor: A zsidótörvények a Közigazgatási Bíróság ítélkezési gyakorlatában. In: MOLNÁR Judit (szerk.): A holokauszt Magyarországon európai perspektívában. Budapest 2005, 164-175.

SCHUMANN, Eva (szerk.): Kontinuitäten und Zäsuren. Rechtswissenschaft und Juristen im „Dritten Reich” und in der Nachkriegszeit. Göttingen 2008

SzEgEDi Gábor: Good Health is the Best Dowry: Marriage, Counseling, Premarital Examinations, Sex Education in Hungary 1920-1952. Msc. Budapest 2014, 307-317.

SzITA Szabolcs: Halálerőd. A munkaszolgálat és a hadimunka történetéhez 1944-1945. ÁKV. Budapest 1989

VOGEL, Joachim: Einflüsse des Nationalsozialismus auf das Strafrecht. Berlin 2004

VORMBAUM, Thomas Einführung in die moderne Strafrechtsgeschichte. Springer 2015

VERES Emőd: Erdély jogtörténete. Kolozsvár 2018 